УДК 621.9

Боровік П. В.

\title{
АНАЛІЗ МОДЕЛІ МЕХАНІЧНИХ ВЛАСТИВОСТЕЙ ПРИ ХОЛОДНОМУ РІЗАННІ МЕТАЛУ НА НОЖИЦЯХ
}

Операції поздовжнього і поперечного різання металопрокату в умовах сучасного прокатного виробництва в більшості випадків виконуються ножицями $[1,2]$, котрі є досить складними машинами за кінематикою та конструкцією. Подальший розвиток процесів і машин для різання, можливий за умови вирішення актуальних завдань по розширенню технологічних можливостей обладнання і підвищенню точності здійснюваних конструкторських розрахунків, а також за рахунок збільшенню ступеня достовірності та наукової обгрунтованості при прийнятті проектних і технологічних рішень.

Безумовним пріоритетом на шляху вирішення, зазначених завдань є експериментальні дослідження процесів обробки тиском. Проте такий підхід $є$ не тільки фінансово та організаційно затратним, а також не завжди здатен забезпечити повноту одержуваної інформації, оскільки це або вимагає цілого ряду додаткових дій, або просто не є можливим з точки зору реалізації. Однак, в сучасних умовах зростання можливостей обчислювальної техніки, а також успішного розвитку методів теоретичних досліджень, що базуються на розробці чисельних математичних моделей, перед дослідниками відкриваються нові перспективи. Ці математичні моделі базуються на законах теорії пружності і пластичності, а також механіки руйнування. А при застосуванні адекватної інформації про механічні властивості конкретного матеріалу, можна в максимально повній мірі відображати реальні фізичні процеси, що відбуваються в металі.

Лідером сьогодення у вирішенні таких задач $є$ метод скінченних елементів (MCE) $[3,4]$, який також застосовується при моделюванні процесів різання металопрокату [5-7].

Головною проблемою у вирішенні даного класу задач $є$ складність отримання достовірних даних щодо кривих текучості і діаграм пластичності в досліджуваних діапазонах температур, ступеня і швидкості деформації.

Так в роботі [8] на базі відомих методів побудови кривих текучості і пластичності був запропонований уточнений метод їх побудови за результатами випробувань на розтягування в залежності від межі текучості і межі міцності матеріалу, а також відносного подовження при розриванні. При застосуванні даного методу енергосилові і кінематичні параметри процесу за результатами моделювання дозволили отримати коефіцієнт кореляції з експериментальними даними більше 0,8 , а відхилення максимальних значень сили різання знаходились в межах $\pm 15 \%$. Однак такі відхилення є досить суттєвими, а отже існує необхідність підвищення точності моделювання, шляхом уточнення моделі механічних властивостей матеріалу.

Метою роботі поставлено задачу уточнення моделі механічних властивостей матеріалу, що дозволяє підвищити достовірність математичного моделювання та точність визначення відповідних енергосилових параметрів процесів холодного розділення металу на ножицях, а також iï аналіз на предмет впливу варіювання параметрів на результати моделювання.

В рамках роботи передбачалося розглянути методику побудови кривих текучості і пластичності на предмет їх уточнення з подальшим скінченно-елементним моделюванням процесу різання на ножицях з паралельними ножами.

При холодному розділенні металопрокату, на відміну від процесу розділення в гарячому стані, механічні властивості розрізуваних сталей в значній мірі залежать від способу виробництва і термічної обробки. У зв'язку з цим в класичних методах розрахунку за основу беруть межу міцності на розтягування розрізуваної марки сталі, однак, при здійсненні розрахунків використовують ряд емпіричних коефіцієнтів [1], які змінюються в широкому діапазоні і можуть в значній мірі впливати на кінцевий результат. 
У довідковій літературі [9], практично для будь-якої марки сталі, можна знайти результати випробувань на розтягування, що характеризуються межею текучості $\sigma_{0,2}$ i межею міцності $\sigma_{b}$ матеріалу при розтягуванні, а також відносним подовженням $\delta$, які враховують спосіб виробництва і термічну обробку металу.

Крім того відомо, що процеси обробки тиском супроводжуються термодинамічними ефектами, проте, в умовах холодної деформації, температура має суперечливий влив на опір різанню, зокрема іiі збільшення призводить до зменшення опору деформації з одночасним його збільшенням при однаковій швидкості деформації. 3 огляду на те, що нагрівання металу має місце в невеликих локальних об'ємах, що не сприяє суттєвому підвищенню точності розрахунків, то впливом термодинамічних ефектів було вирішено знехтувати.

Як вже було показано раніше, важливим фактором при моделюванні процесів розділення є максимально коректний вибір моделі текучості матеріалу. Зокрема для однозначного визначення тензора текучості, необхідна крива течії матеріалу, представлена залежністю, яка може бути отримана апроксимацією діаграми напруження-деформація, отриманої при випробуваннях на розтягування. В літературі [10] представлені різні залежності, отримані апроксимацією цих діаграм.

Серед найбільш широко використовуваних моделей пластичної течії можна виділити модифіковану модель Людвіка-Надаї:

$$
\sigma_{s}\left(\bar{\varepsilon}^{p l}\right)=C_{N}\left(\varepsilon_{0}+\bar{\varepsilon}^{p l}\right)^{n}, \quad \sigma_{s 0}=\sigma_{s}(0)=C_{N}\left(\varepsilon_{0}\right)^{n}
$$

і співвідношення Восе:

$$
\sigma_{s}\left(\bar{\varepsilon}^{p l}\right)=\sigma_{s 0}+C_{V 1}\left(1-e^{-C_{V 2} \bar{\varepsilon}^{p l}}\right)
$$

де $\sigma_{s 0}-$ напруження текучості деформованого матеріалу;

$C_{N}, \varepsilon_{0}, C_{V 1}-$ константи зміцнення;

$C_{V 2}, n-$ показники зміцнення.

Обрана функція повинна забезпечувати найкращу відповідність результатів апроксимації даним, отриманим експериментально.

Відомо, що граничні деформації, що досягаються при випробуванні на розтягування металу в холодному стані, складають $0,2 \ldots 0,4$. Зазначені величини в кілька разів нижче справжніх деформацій в локальних обсягах заготовок при обробці матеріалів тиском. Саме тому результати випробувань на розтягування за стандартними методиками необхідно екстраполювати в сторону великих деформацій, що мають місце при обробці металів тиском.

Приклади можливих помилок екстраполяції проілюстровані на рис. 1, де експериментальна крива деформування порівнюється 3 двома апроксимуючими кривими на основі моделі Надаї і співвідношення Восе. Відмінності між експериментальною і апроксимуючою кривими зростають у міру збільшення пластичної деформації, незважаючи на адекватність обох моделей експериментальним даним при величинах деформацій менше 0,45.

В роботі [10] відзначається, що обидві апроксимації дають задовільні результати при моделюванні МСЕ процесу розділення у гарячому стані, проте потрібні додаткові дані для більш грунтовного вибору апроксимації та визначення констант та показників зміцнення. Перевага апроксимації залежністю Надаї була надана, оскільки в роботі [11], спираючись на експериментальні дані запропонований відносно простий алгоритм розрахунку констант та показників зміцнення для конструкційних матеріалів при статичних випробуваннях

$$
\left(\sigma_{s}=\bar{\sigma}_{(\dot{\varepsilon}=0)}\right): \quad \sigma_{s}=\sigma_{0,2}\left(\bar{\varepsilon}^{p l} / 0,002\right)^{m_{0}},
$$

де $m_{0}-$ показник зміцнення. 


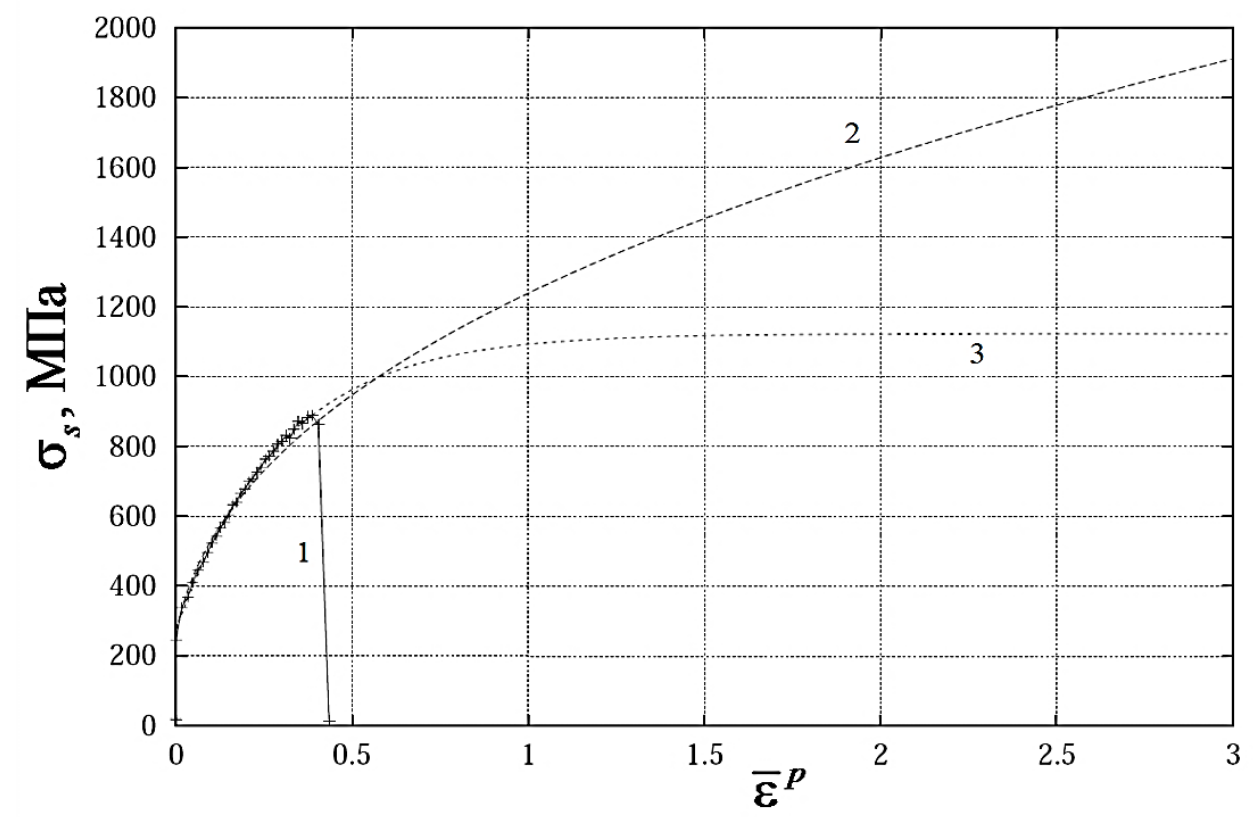

Рис. 1. Криві напруження-деформація:

1 - експериментальна крива; 2 - апроксимація залежністю Надаї; 3 - апроксимація залежністю Восе

На думку авторів роботи [11] значення показника $m_{0}$ залежить від співвідношення межі міцності до межі текучості $\sigma_{b} / \sigma_{0,2}$ при розтягуванні, для визначення якого пропонуються апроксимації для двох ділянок при $\sigma_{b} / \sigma_{0,2} \leq 1,32$ і $\sigma_{b} / \sigma_{0,2}>1,32$ відповідно.

Але, як відомо, істинна (логарифмічна) пластична деформація руйнування при розтягуванні визначається виразом:

$$
\bar{\varepsilon}_{\lim }^{p l}=\ln (1+\delta) .
$$

Також очевидно, що межа міцності матеріалу при розтягуванні і відносне подовження при розриві є взаємопов'язаними параметрами, а саме:

$$
\sigma_{b}=\sigma_{s}\left(\bar{\varepsilon}_{\lim }^{p l}\right)
$$

Проте, визначивши за алгоритмом (3)-(5) значення межі міцності матеріалу при розтягуванні, з розрахунком показника $m_{0}$ як в роботі [11] і порівнявши з фактичними значеннями, було відзначено, що у всіх випадках мають місце завищені значення межі міцності в діапазоні 7,7...42\%.

Таким чином, для обчислення показника зміцнення $m_{0}$ слід в рівняння (2) підставити (4) і дотримавши умову (5), після нескладних перетворень отримати рівняння:

$$
m_{0}=\frac{\ln \left(\frac{\sigma_{b}}{\sigma_{0,2}}\right)}{\ln [500 \cdot \ln (1+\delta)]} .
$$

Для побудови кривих пластичності при розрахунку інтенсивності напружень використовували відому залежність [12], котра дозволяє врахувати швидкість деформації: 


$$
\bar{\sigma}=\sigma_{S} K_{v}=\sigma_{S}\left(\frac{\dot{\varepsilon}}{\dot{\varepsilon}_{S}}\right)^{m}
$$

де $K_{v}$ - швидкісний коефіцієнт;

$\dot{\varepsilon}$ - поточна швидкість деформації;

$\dot{\varepsilon}_{S}$ - швидкість деформації, при статичних випробуваннях, котра зазвичай становить $\dot{\varepsilon}_{S}=10^{-5} \ldots 10^{-3} \mathrm{c}^{-1}$;

$m$ - показник швидкісного зміцнення. За даними досліджень Губкіна С. І., для сталей при температурі деформації, що відноситься до зони повного зміцнення, були отримані значення в діапазоні $m=0,02125 \ldots 0,0425$. При цьому, слід зазначити, що більші значення відповідають більшим температурам цього інтервалу.

Аналогічно, з урахуванням виразу (4) і умови (5), доцільно перетворити апроксимацію діаграм пластичності О. А. Лабутіна і Г. О. Смирнова-Аляєва, які представляють собою залежність пластичної деформації руйнування $\bar{\varepsilon}_{f}$ (граничної пластичної деформації) від відповідного показника напруженого стану $k$ :

$$
\bar{\varepsilon}_{f}^{p l}=2 \ln (1+\delta) e^{-0,72 k},
$$

де $k$ - показник напруженого стану, запропонований Г. О. Смирновим-Аляєвим [11] і визначається відношенням:

$$
k=\frac{I_{1}\left(T_{\sigma}\right)}{\sqrt{3\left|I_{2}\left(D_{\sigma}\right)\right|}}=\frac{\sigma_{1}+\sigma_{2}+\sigma_{3}}{q},
$$

де $I_{1}\left(T_{\sigma}\right)$ - перший інваріант тензора напружень:

$$
I_{1}\left(T_{\sigma}\right)=\sigma_{1}+\sigma_{2}+\sigma_{3}
$$

$I_{2}\left(D_{\sigma}\right)$ - другий інваріант девіатора напружень:

$$
I_{2}\left(D_{\sigma}\right)=\left(\sigma_{1}-\sigma\right)\left(\sigma_{2}-\sigma\right)+\left(\sigma_{2}-\sigma\right)\left(\sigma_{3}-\sigma\right)+\left(\sigma_{1}-\sigma\right)\left(\sigma_{3}-\sigma\right) ;
$$

$\sigma_{1}, \sigma_{2}, \sigma_{3}$ - головні напруження;

$q$ - інтенсивність напружень по Мізесу:

$$
q=\sqrt{3\left|I_{2}\left(D_{\sigma}\right)\right|}=\sqrt{\frac{\left(\sigma_{1}-\sigma_{2}\right)^{2}+\left(\sigma_{2}-\sigma_{3}\right)^{2}+\left(\sigma_{1}-\sigma_{3}\right)^{2}}{2}} .
$$

Отже показник напруженого стану, запропонований Г. О. Смирновим-Аляєвим через головні напруження має вид:

$$
k=\sqrt{2} \frac{\sigma_{1}+\sigma_{2}+\sigma_{3}}{\sqrt{\left(\sigma_{1}-\sigma_{2}\right)^{2}+\left(\sigma_{2}-\sigma_{3}\right)^{2}+\left(\sigma_{1}-\sigma_{3}\right)^{2}}}
$$

Проте в Abaqus для визначення показника трьохосного напруженого стану застосовують рівняння:

$$
\eta=\frac{-p}{q}
$$

$p$ - гідростатичний тиск. 
Відповідно, в результаті співставлення маємо:

$$
\eta=k / 3 \Rightarrow k=3 \eta \text {. }
$$

3 урахування співвідношення (15) рівняння (8) при застосуванні в Abaqus повинне мати наступний вид:

$$
\bar{\varepsilon}_{f}^{p l}=2 \ln (1+\delta) e^{-2,16 \eta} .
$$

Однак, головним недоліком рівняння (16) є те, що воно не враховує швидкість пластичної деформації $\dot{\bar{\varepsilon}} p l$. За для їі врахування, використовували твердження, що при досягненні в зразку критичної довжини тріщини для досліджуваного матеріалу значення питомої енергії руйнування прагнуть до постійної величини, котре є результатом дослідницьких робіт в області досліджень механіки руйнування та міцності матеріалів під керівництвом академіка Панасюка В. В. [13]. Тобто отримаємо:

$$
\int_{0}^{\bar{\varepsilon}^{p l} f(\dot{\varepsilon}=0)} \bar{\sigma}_{(\dot{\varepsilon}=0)} d \bar{\varepsilon}^{p l}=\int_{0}^{\bar{\varepsilon}^{p l} f(\dot{\varepsilon}>0)} \bar{\sigma}_{(\dot{\varepsilon}>0)} d \bar{\varepsilon}^{p l} .
$$

У урахуванням рівнянь (3) та (7) перетворимо (17) до виду:

$$
\int_{0}^{\bar{\varepsilon}_{f l}^{p l}(\dot{\varepsilon}=0)} \sigma_{0,2}\left(\bar{\varepsilon}^{p l} / 0,002\right)^{m_{0}} d \bar{\varepsilon}^{p l}=\int_{0}^{\bar{\varepsilon}_{f l}^{p l}(\dot{\varepsilon}>0)} K_{v} \sigma_{0,2}\left(\bar{\varepsilon}^{p l} / 0,002\right)^{m_{0}} d \bar{\varepsilon}^{p l} .
$$

Після інтегрування та нескладних перетворень отримаємо:

$$
\bar{\varepsilon}_{f(\dot{\varepsilon}>0)}^{p l}=\bar{\varepsilon}_{f(\dot{\varepsilon}=0)}^{p l} / K_{v}{ }^{\frac{1}{m_{0}+1}} .
$$

Ініціювання критерію початку ушкоджень в матеріалі відбувається, коли виконується умова:

$$
\omega_{D}=\int \frac{d \bar{\varepsilon}^{p l}}{\bar{\varepsilon}_{D}^{p l}}=1,
$$

де $\omega_{D}$ - змінна стану, що монотонно зростає зі збільшенням пластичної деформації.

При кожному кроку часу аналізу приріст змінної стану $\omega_{D}$ визначається як:

$$
\Delta \omega_{D}=\Delta \bar{\varepsilon}^{p l} / \bar{\varepsilon}_{D}^{p l} \geq 0 .
$$

На рис. 2 продемонстровано в порівнянні характерну поведінку в ході деформації матеріалу з ізотропним зміцненням без пошкоджень та при наявності пошкоджень. В контексті пружного матеріалу з ізотропним зміцненням пошкодження проявляються в зниженні межі текучості і пружності. Суцільна крива представляє криву текучості матеріалу з урахуванням накопичення пошкоджень в ході деформації, тоді як пунктирна крива їх не враховує. При цьому слід зазначити, що характер та параметри цих кривих можуть змінюватися для одного й того матеріалу при зміні швидкості деформації.

На рис. 2 можна бачити, що до певного значення еквівалентної пластичної деформації $\bar{\varepsilon}_{0}^{p l}$ модуль пружності матеріалу $E$ залишається незмінним, а пошкодження в матеріалі відсутні $(D=0)$. При подальшому збільшенні еквівалентної пластичної деформації в матеріалі накопичуються ушкодження до настання повного руйнування при $\bar{\varepsilon}_{f}^{p l}$, коли сумарне значення ушкоджень сягає $D=1$. 


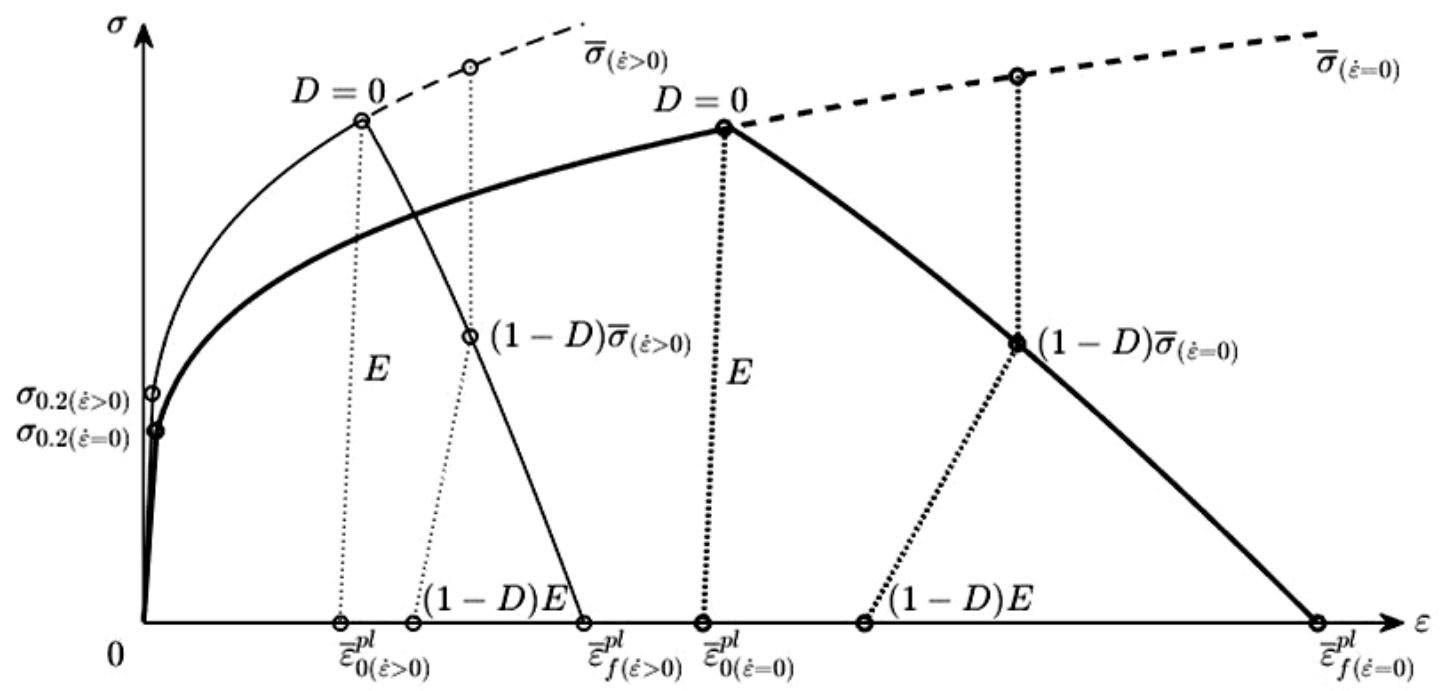

Рис. 2. Характерні криві деформації матеріалу 3 ізотропним зміцненням без пошкоджень (---) та при наявності пошкоджень (-) при статичній швидкості деформації $(\dot{\varepsilon}=0)$ та швидкості більшій за статичну $(\dot{\varepsilon}>0)$

Еквівалентна пластична деформація руйнування $\bar{\varepsilon}_{f}^{p l}$ для пластичних матеріалів може бути визначена $з$ діаграми пластичності (рис. 3) в залежності від показника напруженого стану та швидкості пластичної деформації. Проте цей показник $є$ інтегральним, оскільки в експериментах визначається для всього зруйнованого перетину, хоча в локальних об'ємах мають місце як більші так і менші значення пластичної деформації. Насамперед, це пояснюється тим, що ці локальні об'єми руйнуються не одночасно і мають в ці моменти дещо різні показники напруженого стану. Проте визначити їх експериментально не представляється можливим і за результат беруть узагальнені значення.

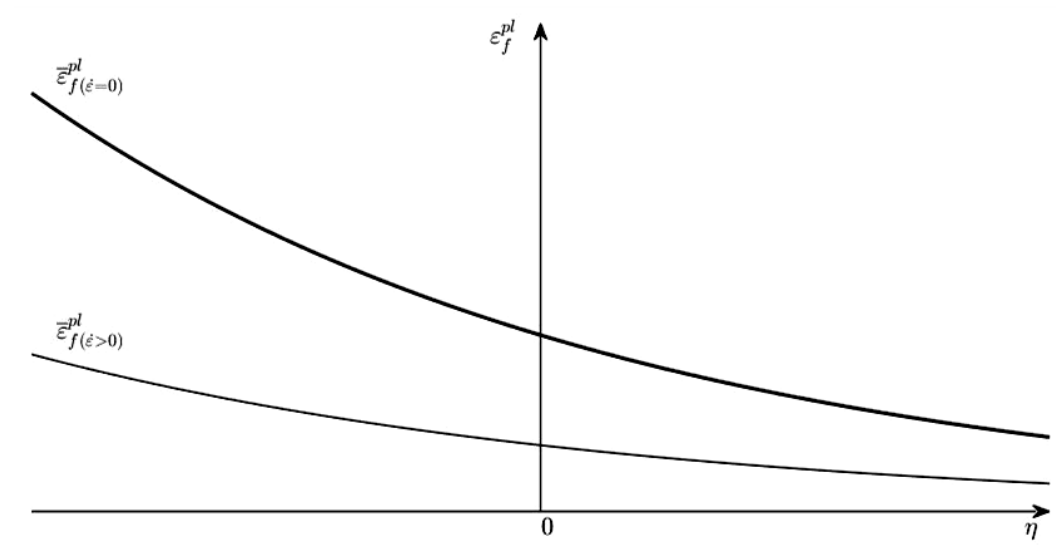

Рис. 3. Характерні діаграми пластичності пластичного матеріалу при статичній швидкості деформації $(\dot{\varepsilon}=0)$ та швидкості більшій за статичну $(\dot{\varepsilon}>0)$

Саме такий підхід стосовно скінченних елементів запропонував Хіллерборг (Hillerborg). В основі даного підходу, використовується концепція крихкого руйнування, що визначає енергію, необхідну для відкриття одиничної області тріщини, як параметр матеріалу. При такому підході втрата міцності після виникнення пошкоджень характеризується зниженням напруження. Тобто при досягненні інтегрального показника еквівалентної пластичної деформації величини пластичної деформації руйнування $\bar{\varepsilon}_{f}^{p l}$, вважається, що в даному скінченному елементі починають накопичуватися пошкодження, котрі зменшують 
напруження. Таким чином, очевидно, що пластична деформація руйнування $\bar{\varepsilon}_{f}^{p l}$ буде різною для скінченних елементів різного розміру і тому не може використовуватися в якості параметра матеріалу для специфікації закону розвитку пошкоджень в матеріалі.

Підхід Хіллеборга дозволяє закон розвитку пошкоджень в матеріалі визначити у вигляді еквівалентного пластичного переміщення $\bar{u} p l$ або розсіювання енергії руйнування $G_{f}$, що зводить до мінімуму залежність результатів від сітки.

Реалізація цієї концепції в МСЕ вимагає визначення характеристичної довжини $L$, пов'язаної з точкою інтегрування. Енергія руйнування тоді визначається як:

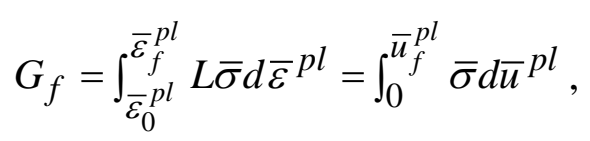

де $\bar{u}_{f}^{p l}$ - ефективне пластичне переміщення, при якому відбувається повне руйнування.

Рівняння (22) вводить визначення еквівалентного пластичного переміщення $\bar{u}$, оскільки робота руйнування пов'язана з межею текучості після ініціації пошкоджень (робота на одиницю площі тріщини). При цьому до моменту початку пошкодження $\dot{\bar{u}}^{p l}=0$, після початку пошкодження $\dot{\bar{u}}^{p l}=L \dot{\bar{\varepsilon}}^{p l}$ або $d \bar{u}^{p l}=L d \bar{\varepsilon}^{p l}$.

Потім, використовуючи МСЕ, здійснювалося моделювання процесу холодної різання паралельними ножами на базі програмного комплексу Abaqus. Математична модель описувала плоску задачу різання паралельними ножами з урахуванням жорсткості станини.

В якості вихідних даних для моделювання були взяті результати експериментальних досліджень процесу холодної різання паралельними ножами наведені в роботі [1].

У таблиці 1 наведені, назви матеріалів, їх механічні властивості, розмір заготовок становив $25 \times 25$ мм, а швидкість різання паралельними ножами 300 мм/с.

За результатами моделювання МСЕ були отримані відповідні залежності сили різання, котрі досить добре корелюють з експериментальними кривими, проте максимальні значення сил різання коливались в межах \pm 15 \% в порівнянні з експериментом.

На рис. 4, а можна бачити, що величина відносної похибки дуже добре корелює $(R=-0,92658)$ з відносним подовженням $\delta$ при розриванні, що може свідчити про їі системність, через втрату одного з факторів.

Зокрема в рівнянні (7) швидкість деформації $\dot{\varepsilon}_{S}$, при статичних випробуваннях, може коливатися в широкому діапазоні, а в попередніх моделях при визначенні механічних властивостей іï приймали рівною $\dot{\varepsilon}_{S}=10^{-4} \mathrm{c}^{-1}$. Тому на наступному етапі, методом перебору визначали швидкість деформації, при статичних випробуваннях з метою отримання мінімальної відносної похибки моделювання МСЕ:

$$
\Delta P\left(\dot{\varepsilon}_{S}\right) \rightarrow \min
$$

В результаті були отримані дані, котрі при обробці методом найменших квадратів, дозволили отримати рівняння регресії, щодо визначення швидкості деформації $\dot{\varepsilon}_{S}$, при статичних випробуваннях:

$$
\dot{\varepsilon}_{S}=e^{-3,5-21 \delta}
$$

На рис. 4, б представлені розрахункові значення швидкості деформації $\dot{\varepsilon}_{S}$, при статичних випробуваннях та визначені з рівняння (24), коефіцієнт кореляції між якими становить $R=0,98964$. 
Застосування рівняння (24) при повторному моделюванні МСЕ дозволило зменшити відносну похибку до $\pm 7 \%$.

Таблиця 1

Характеристика експериментальних зразків

\begin{tabular}{|c|l|c|c|c|}
\hline № 3/п & \multicolumn{1}{|c|}{ Марка матеріалу* } & $\sigma_{0,2}, \mathrm{M \Pi а}$ & $\sigma_{b}, \mathrm{MПа}$ & $\delta$ \\
\hline 1 & Сталь 20 & 418 & 527 & 0,217 \\
\hline 2 & Сталь 45 (канатна сталь) & 347 & 660 & 0,197 \\
\hline 3 & ШХ10 & 439 & 822 & 0,166 \\
\hline 4 & Сталь 75 (пружинна сталь) & 574 & 989 & 0,108 \\
\hline 5 & Сталь 15 (1015) & 177 & 373 & 0,32 \\
\hline 6 & Сталь 18Х2Н4ВА (Э16) & 910 & 1128 & 0,09 \\
\hline 7 & Сталь 12Х18Н9 (ЭЯ1) & 230 & 589 & 0,45 \\
\hline
\end{tabular}

* - в дужках вказані назви у відповідності з даними О. І. Целікова [1]

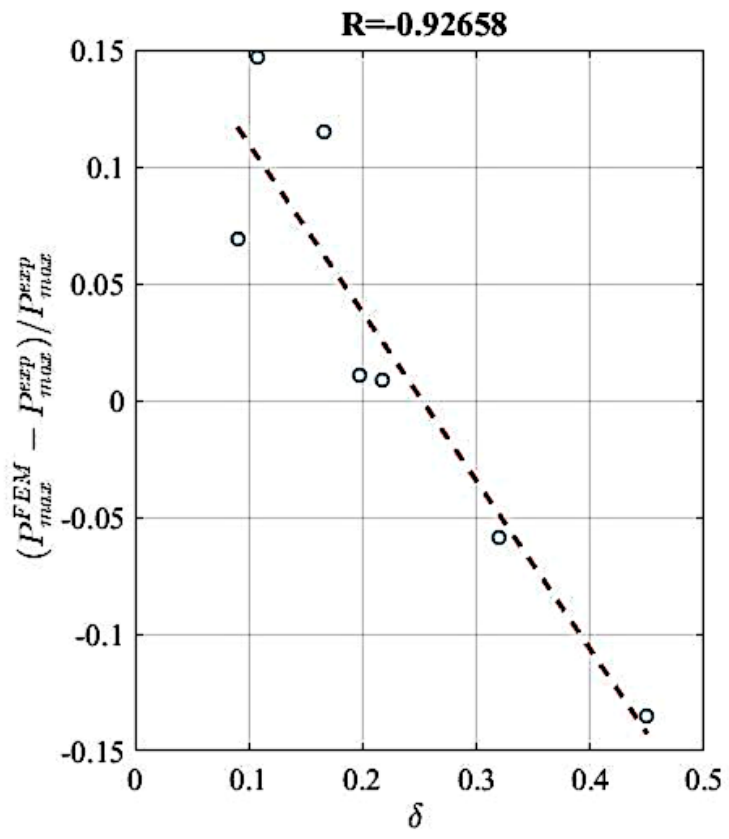

$\mathrm{a}$

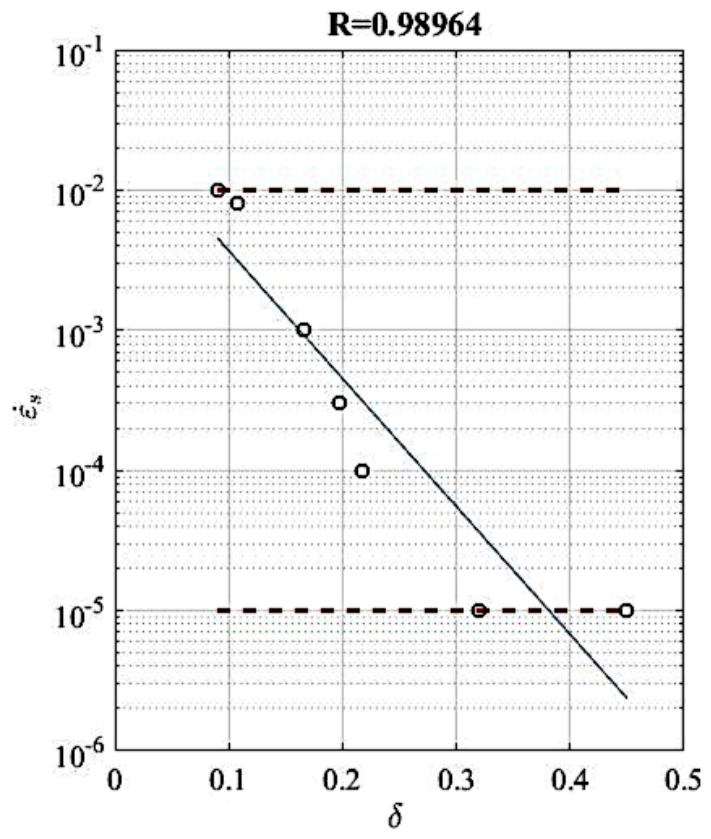

6

Рис. 4. Залежності величини відносної похибки $\Delta P_{\max }$ з відносним подовженням $\delta$ при розриванні (а) та розрахункові значення швидкості деформації $\dot{\varepsilon}_{S}$ (б), при статичних випробуваннях, визначені при моделюванні $\mathrm{MCE}$ (о) та розраховані (-) з рівняння (21)

Для оцінки впливу варіювання параметрів на результати моделювання здійснювали моделювання процесу різання МСЕ за умов варіювання швидкістю різання, межею текучості, відносним подовженням при розтягуванні, висотою розрізуваного перерізу. Зокрема аналізували частинний вплив означених параметрів на максимальний опір різанню $\tau_{\max }$ (рис. 5).

На рис. 5, а представлені залежності відношення максимального опору різання при кожній відносній швидкості різання $\tau_{\max }\left(V_{h_{i}}\right)$ до відповідного значення $\tau_{\max }\left(V_{h}=12\right)$ 
отриманого при відносній швидкості $V_{h}=12 c^{-1}(V=300 \mu м / c)$ для різних відносних швидкостей $V_{h}$. Як можна бачити, для представлених марок сталей, в досліджуваному діапазоні спостерігається зменшення в межах $4 . .6 \%$ максимального значення опору різанню зі зменшенням швидкості різання.

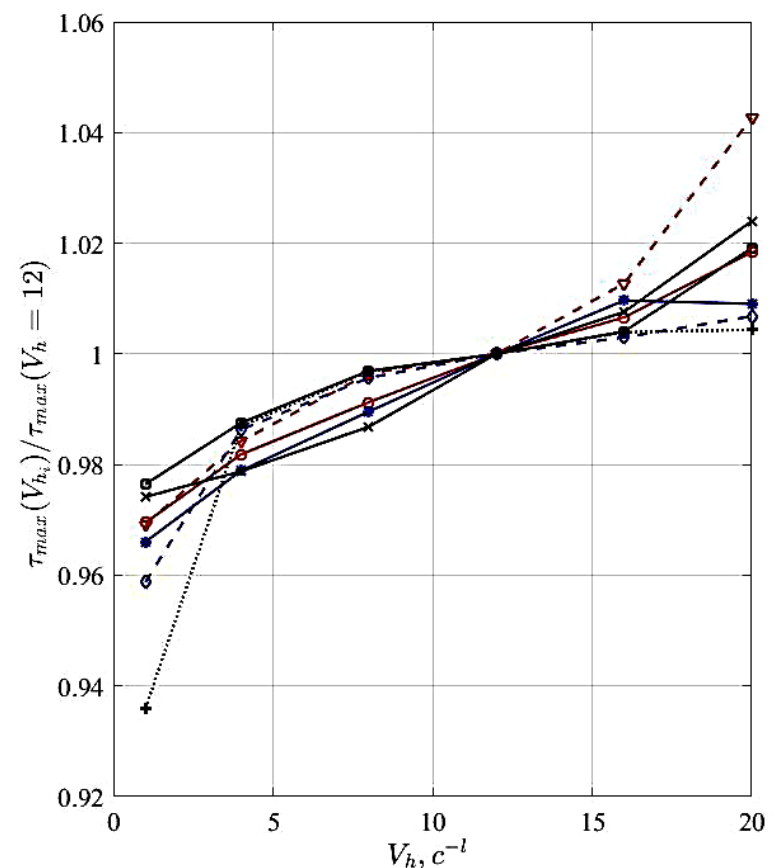

a

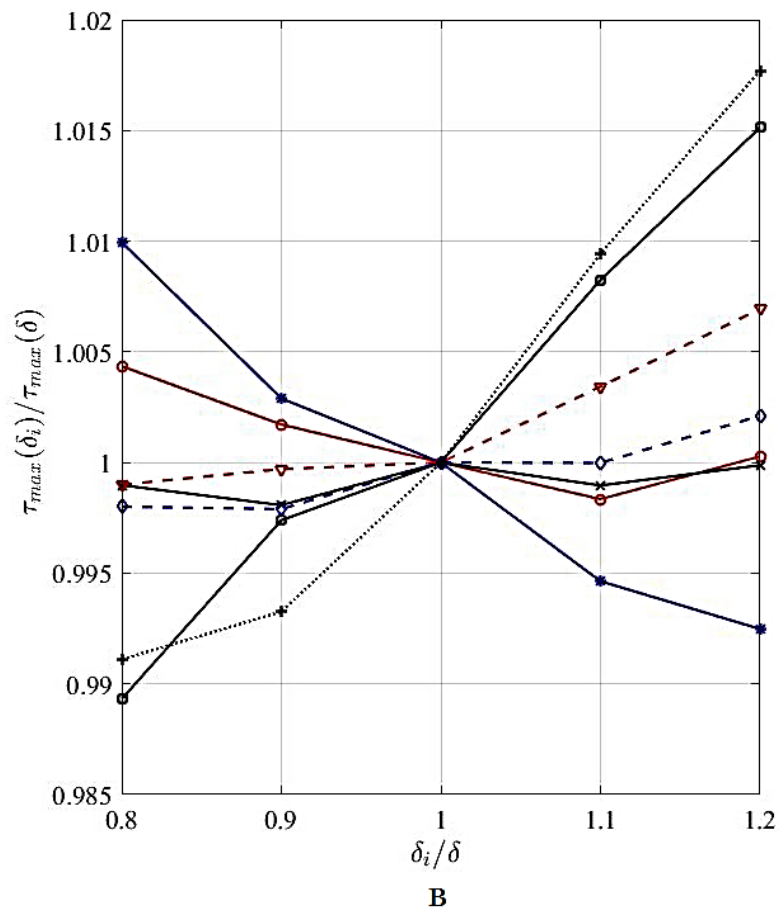

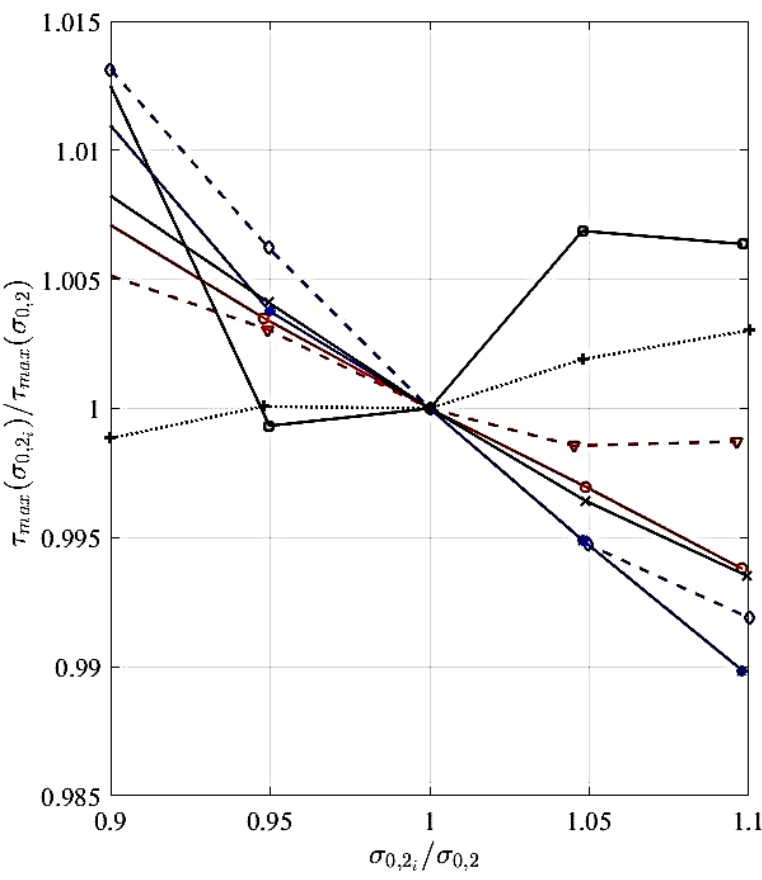

6

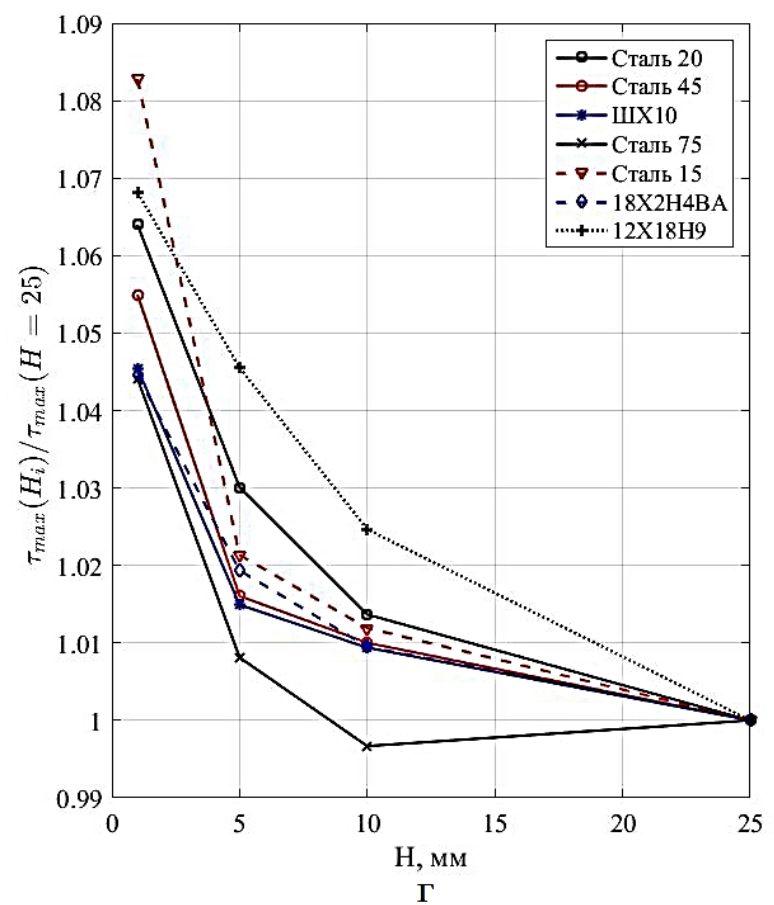

Рис. 5. Залежності відношення максимального опору різанню $\tau_{\max }$ при різних значеннях відносної швидкості різання $V_{h_{i}}$, межи текучості $\sigma_{0.2_{i}}$ (б) відносного подовження при розтягуванні $\delta_{i}$ (в), висоти розрізуваного перерізу $H_{i}$ (г) до відповідних значень отриманих експериментальних даних О. І. Целікова [1] 
На рис. 5, б представлені відповідні залежності відношення максимального опору різанню $\tau_{\max }\left(\sigma_{0,2_{i}}\right)$ при варіюванні значення межи текучості в діапазоні $\pm 10 \% \sigma_{0,2}$ до значення межи текучості за даними експериментів $\tau_{\max }\left(\sigma_{0,2}\right)$. Як можна бачити з представлених залежностей вплив даного параметру на максимальне значення опору різанню практично не помітний, оскільки не перевищує $1,5 \%$, що цілком можливо $є$ накопичуваною похибкою машинного розрахунку.

Аналогічно досліджувався частинний вплив відносного подовження при розтягуванні в діапазоні $\pm 20 \%$ від значення у матеріалу за даними експериментів $\delta$. На рис. 5 , в представлені відповідні залежності відношення максимального опору різання $\tau_{\max }\left(\delta_{i}\right)$ при варіюванні відносного подовження при розтягуванні до значення за даними експериментів $\tau_{\max }(\delta)$. Аналіз отриманих залежностей вказує, що вплив даного параметру в зазначеному діапазоні практично незначний для максимального опору різання (в межах накопичуваної похибки машинного розрахунку).

Також вивчався частинний вплив висоти перерізу металу при різанні. При цьому, для отримання максимально наближених до частинного впливу результатів застосовували наступні обмеження:

- відносну швидкість різання утримували на рівні $V_{h}=12 c^{-1}$, шляхом пропорційного зменшення швидкості руху ножа;

- величину ефективного пластичного переміщення, при якому відбувається повне руйнування $\bar{u}_{f}^{p l}$, змінювали пропорційно висоті висоти перерізу металу при різанні.

Залежності відношення максимального опору різанню $\tau_{\max }\left(H_{i}\right)$ при різних значеннях висоти розрізуваного перерізу $H_{i}$ до відповідного значення отриманого при висоти розрізуваного перерізу $H=25$ мм представлені на рис. 5, г. Як можна бачити, при зменшенні висоти перерізу в досліджуваному діапазоні від 25 до 1 мм, прослідковується чітка тенденція до збільшення максимального опору різанню межах 4 ...9\%.

\section{ВИСНОВКИ}

За результатами роботи можна зробити наступні висновки:

- концепція крихкого руйнування, що визначає енергію, необхідну для відкриття одиничної області тріщини, як параметр матеріалу, може застосовуватися при моделюванні процесів холодного розділення методом скінченних елементів;

- величина швидкості деформації, при статичних випробуваннях, має тісний зв'язок із відносним подовженням матеріалу при розриванні, а врахування цього фактору дозволяє уточнити модель механічних властивостей матеріалу та підвищити достовірність математичного моделювання процесів холодного розділення металу на ножицях;

- загалом результати моделювання не протирічать загальним уявленням про процеси розділення металів у холодному стані;

- представлена математична модель механічних властивостей матеріалу 3 високим ступенем адекватності моделює реальні процеси розділення металопрокату.

Результати роботи можна рекомендувати до використання при прийнятті проектноконструкторських та технологічних рішень в питаннях холодного розділення металу на ножицях.

\section{СПИСОК ВИКОРИСТАНОЇ ЛІТЕРАТУРИ}

1. Лукашин Н. Д., Кохан Л. С., Якушев А. М. Конструкция и расчет машин и агрегатов металлургических заводов: учебник для вузов. Москва: ИКЦ «Академкнига», 2003. 456 с.

2. Siddhartha Ray. Principles and Applications of Metal Rolling. Cambridge University Press. 2016. 320 p.

3. Amar Khennane. Introduction to Finite Element Analysis Using MATLAB and Abaqus. CRC Press. 2013. 487 p.

4. Боровік П. В. Теоретичні дослідження процесів обробки металів тиском на основі методу скінчених елементів: навч. посіб. Алчевськ: ДонДТУ, 2012. 170 с. 
5. Gustafsson E., Marth S., Karlsson L. et al. Strain and stress conditions at crack initiation during shearing of medium- and high-strength steel sheet. International Journal of Mechanical and Materials Engineering. 2017. DOI: https://doi.org/10.1186/s40712-017-0075-5.

6. Reimer P., Zehetner Ch., Hammelmüller F. et al. Numerical modelling and simulation of sheet metal cutting processes. 7th European Congress on Computational Methods in Applied Sciences and Engineering. 2016, pp. 7749-7756. DOI: $10.7712 / 100016.2370 .10183$

7. Bohdal L. Application of FEM and vision-based methods to analysis of shearing processes in the aspect of scrap reduction. Annual Set the Environment Protection. 2015. 17, pp. 90-103.

8. Боровик П. В. Метод построения кривых текучести и пластичности при трехмерном моделировании процессов холодной резки на ножницах. Вісник НТУ "ХПI". 2018.31 (1307). С. 8-13.

9. Зубченко А. С., Колосков М. М., Каширский Ю. В. и др. Марочник сталей и сплавов. Под общей ред. А. С. Зубченко. Москва: Машиностроение, 2003. 784 с.

10. Боровик П. В., Луценко В. А. Выбор аппроксимации механических свойств при математическом моделировании процесса горячей резки на ножницах. Металлургические процессы и оборудование. Донецк, 2011. 2(24). С. 5-9.

11. Гохфельд Д. А., Гецов Л. Б., Кононов К. М. и др. Механические свойства сталей и сплавов при нестационарном нагружении: справочник. Екатеринбург: УрО РАН. 1996. 408 с.

12. Ушаков М. В., Ильюхин С. Ю., Воробьев И. А. Учет влияния скорости деформации и температуры на процессы, происходящие в зоне первичной деформации при резании металлов. Известия ТулГУ. Технические науки. 4. 2. 2010. С. 89-93.

13. Панасюк В. В., Андрейкив А. Е., Ковчик С. Е. Методы оценки трещиностойкости конструкционных материалов. Киев: Наукова думка. 1977. 279 с.

\section{REFERENCES}

1. Lukashin N.D., Kokhan L.S., Yakushev A.M. Design and calculation of machines and devices of metallurgical plants: textbook for universities. Moscow: Akademkniga. 2003. 456 p. (in Russian).

2.Siddhartha Ray. Principles and Applications of Metal Rolling. Cambridge University Press. 2016. 320 p.

3. Amar Khennane. Introduction to Finite Element Analysis Using MATLAB and Abaqus. CRC Press. 2013. 487 p.

4. Borovik P.V. Theoretical researhes of metalls processes working by pressure based on the finite elements method. Alchevsk. DonSTU. 2012. 170 p. (in Russian).

5. Gustafsson E., Marth S., Karlsson L. et al. Strain and stress conditions at crack initiation during shearing of medium- and high-strength steel sheet. International Journal of Mechanical and Materials Engineering. 2017.

DOI: https://doi.org/10.1186/s40712-017-0075-5

6. Reimer P., Zehetner Ch., Hammelmüller F. et al. Numerical modelling and simulation of sheet metal cutting processes. 7th European Congress on Computational Methods in Applied Sciences and Engineering. 2016, pp. 7749-7756. DOI: $10.7712 / 100016.2370 .10183$

7. Bohdal L. Application of FEM and vision-based methods to analysis of shearing processes in the aspect of scrap reduction. Annual Set the Environment Protection. 2015.17, pp. 90-103.

8. Borovik P.V. A method for determination of the stress-strain curves and ductility curves in 3d modeling of cold separating processes on shears. Bulletin of NTU “KhPI”. 2018. 31 (1307), pp. 8-13. (in Russian).

9. Zubchenko A.S., Koloskov M.M., Yu. V. Kashirsky Yu. V. et al. Database steels and alloys. Ed. A.S. Zubchenko. Moscow: Mechanical Engineering, 2003. 784 p. (in Russian).

10. Borovik P.V., Lutsenko V.A. Approximation of mechanical properties at the mathematical modeling of hot cutting process on scissors. Metallurgical processes and equipment. Donetsk. 2011. 2(24), pp. 5-9. (in Russian).

11. Gokhfeld D.A., Getsov L.B., Kononov K.M. et al. Mechanical properties of steels and alloys under nonstationary loading: a handbook. Yekaterinburg: Ural Branch of RAS. 1996. 408 p. (in Russian).

12. Ushakov M.V., Ilyukhin S. Yu., Vorobyev I.A. Accounting for the effect of the deformation rate and temperature on the processes occurring in the zone of primary deformation when cutting metals. Bulletin of TulSU. Technical science. 4. 2. Tula: TulSU. 2010, pp. 89-93. (in Russian).

13. Panasyuk V.V., Andreykiv A.E., Kovchik S.E. Methods for assessing the crack resistance of structural materials. Kyiv: Scientific Opinion. 1977. 279 c. (in Russian).

Боровік П. В. - - канд. техн. наук, СНУ ім. В. Даля.

СНУ ім. В. Даля - Східноукраїнський національний університет імені Володимира Даля, м. Сєвєродонецьк.

E-mail: borovikpv@ukr.net 